Situs Jurnal : $\underline{\text { http://ejurnal.stiepancasetia.ac.id/index.php/jieb }}$

Jilid 4 Nomor 2 Juli 2018

Hal $191-201$

\title{
PENGARUH PENGEMBANGAN SUMBER DAYA MANUSIA TERHADAP KINERJA DI LINGKUNGAN PEMERINTAHAN KABUPATEN MURUNG RAYA
}

\section{Firdaus*}

Abstract: This study aims to determine whether there is influence of human resource development on performance in the Government of Murung Raya Regency either partially or simultaneously. The method used in this study is quantitative research is a research model that requires the existence of the calculation of the numbers, while the approach used is a survey approach that is research that takes a sample of the population and use the questionnaire as a basic data collection tool. The results of this study indicate that the development of human resources influence significantly and changes in the direction of the performance of employees in the Government of Murung Raya Regency.

\section{Keywords: Human Resources development, Performance, Murung Raya Regency}

Abstrak: Penelitian ini bertujuan untuk mengetahui ada tidaknya pengaruh pengembangan Sumber Daya Manusia terhadap kinerja di lingkungan Pemerintahan Kabupaten Murung Raya baik secara parsial maupun simultan. Metode yang digunakan dalam penelitian ini adalah penelitian kuantitatif yaitu suatu model penelitian yang mengharuskan akan adanya perhitungan angka-angka, sedangkan pendekatan yang digunakan adalah dengan pendekatan survei yaitu penelitian yang mengambil sampel dari populasi dan menggunakan kuesioner sebagai alat pengumpulan data yang pokok. Hasil penelitian ini menunjukan bahwa pengembangan sumber daya manusia berpengaruh secara siginifikan dan perubahannya berubah searah dengan tingkat kinerja pegawai di lingkungan Pemerintahan Kabupaten Murung Raya

Kata kunci : pengembangan sumber daya manusia, kinerja, Kabupaten Murung Raya

\section{Latar Belakang}

Sumber daya manusia mempunyai peranan yang sangat penting, dalam interaksinya dengan faktor modal, material, metode, dan mesin. Kompleksitas yang ada dapat menentukan kualitas manusia. Oleh karena itu mengharuskan kita untuk selalu berhati-hati dan memperhatikan setiap aspeknya. Hal ini, sebagaimana yang dikemukakan oleh Snyder (1989) bahwa "Manusia merupakan sumber daya yang paling bernilai, dan ilmu perilaku menyiapkan banyak teknik dan program yang dapat menuntun pemanfaatan sumber daya manusia secara lebih efektif." Hal ini bertujuan untuk mencapai kinerja sumber daya manusia yang semakin meningkat.

Dewasa ini bangsa Indonesia untuk menghadapi tantangan pada era globalisasi berusaha untuk dapat membuka peluang berbagai usaha. Oleh karena itu sebuah organisasi baik organisasi publik maupun organisasi swasta dituntut mampu memicu diri untuk mempersiapkan sumber daya manusia yang dimiliki. Organisasi harus memiliki tujuan yang hendak dicapai dengan jelas, untuk mencapai tujuan, organisasi harus dapat mendayagunakan berbagi potensi yang ada salah satunya adalah sumber daya manusia. Sumber daya manusia 
mempunyai peran yang sangat penting dan mutlak harus ada pada organisasi dan dikembangkan selaras dengan kemajuan ilmu dan teknologi, sebagaimana diungkapkan Harlison dan Meyers dikutip Tjiptoheriyanto dan Soemitro (1998:56) menyatakan meskipun modal sumber daya alam, bantuan luar negeri dan pandangan luar negeri memainkan peran penting dari pertumbuhan ekonomi, namun tidak ada diantaranya dan lebih ditekankan dari pada sumber daya manusia.

Sumber daya manusia merupakan faktor yang sangat sentral dalam organisasi,apapun bentuk dan tujuannya, organisasi dibuat berdasarkan berbagai visi untuk kepentingan manusia. Pentingnya sumber daya manusia dalam suatu organisasi, menuntut setiap organisasi mendapatkan pegawai yang berkualitas dan produktif untuk menjalankan organisasi. Manajemen sumber daya manusia pada era informasi ini. Menurut Dessler (2003:36) yaitu: "Strategic Human Resource Management is the linking of Human Resource Management with strategic role and objectives in order to improve business performance and develop organizational cultures and foster innovation and flexibility". Terlihat bahwa para pimpinan organisasi harus mengaitkan pelaksanaan manajemen sumber daya manusia dengan strategi organisasi untuk meningkatkan kinerja serta mengembangkan budaya organisasi yang akan mendukung penerapan inovasi dan fleksibilitas.

Penekanan pada sumber daya manusia sebagai modal berharga dalam organisasi mencerminkan pekanan lebih pada sumber daya tak berwujud daripada yang nyata. Sebagaimana yang dikemukakan oleh (Becker, 1964) bahwa investasi sumber daya manusia bertujuan untuk mendapatkan keuntungan bagi organisasi baik dalam jangka panjang atau pendek. Melalui keterampilan dan kemampuan yang dimiliki karyawan akan termotivasi untuk terus belajar membangun lingkungan bisnis yang unggul. Sumber daya manusia digunakan secara signifikan sebagai penggerak sumber daya lain dan memiliki posisi strategis yang berkontribusi untuk mewujudkan kinerja organisasi perusahaan dengan keunggulan kompetitif (Wright: 2005).

Paulus dan Anantharaman (2003) menegaskan pengembangan sumber daya manusia memiliki hubungan langsung dengan profitabilitas organisasi. Oleh karena itu, setiap organisasi disarankan untuk mengoptimalkan kinerja karyawan dalam memberikan kontribusi yang optimal, antara lain dengan cara melakukan program pelatihan dan pengembangan. Hal ini juga berhubungan dengan produktivitas organisasi dan dapat meningkatkan efektivitas dan efisiensi pekerjaan.

Demikian pula halnya dengan organisasi pemerintah, di mana kinerja pegawai terkait erat dengan penyediaan layanan kepada publik. Meskipun merupakan sebuah organisasi nonprofit, pegawai harus memiliki standar kualifikasi tinggi karena hal tersebut dapat mempengaruhi kredibilitas lembaga pemerintah. Salah satu indikator yang dimiliki oleh pegawai adalah pendidikan. Faktor-faktor lain dari pengembangan sumber daya manusia memiliki hubungan dengan kinerja pegawai seperti pengembangan karir, mutasi, promosi pekerjaan, dan kompensasi. Melalui pengembangan tersebut, pegawai akan bekerja dengan prinsip transparansi dan profesionalisme sebagai penggerak utama yang pada akhirnya akan menciptakan tatapemerintahan yang baik.

Melihat besarnya peran sumber daya manusia untuk pencapaian tujuan organisasi, maka kehadiran sumber daya manusia yang memiliki kecakapan dan keterampilan sangat dibutuhkan. Oleh karena itu perlu adanya tindakan pemeliharaan dan pengembangan sumber daya manusia sebagai aset organisasi, jika sumber daya manusia dianggap sebagai sumber daya penting untuk sebuah organisasi, maka salah satu implementasinya adalah investasi yang harus dilakukan oleh pimpinan organisasi adalah investasi pada bidang sumber daya manusia. Bahkan dalam konsep kontemporer saat ini konsep resources telah diubah menjadi capital untuk mendefinisikan ulang konsep sumberdaya manusia, sehingga diperkenalkan istilah human capital. Istilah human capital telah banyak digunakan untuk menggantikan human 
resources. Menurutnya pada konsep human capital, organisasi memperlakukan orang bukan sebagai faktor biaya melainkan sebagai asset (harta) (Hutapea \& Thoha, 2008:108). Artinya, organisasi menganggap setiap biaya yang dikeluarkan untuk pengembangan sumberdaya manusia adalah investasi, yang mana pada akhirnya biaya-biaya tersebut akan memberikan hasil pada organisasi.

Kinerja seseorang (human performance) merupakan fungsi dari kemampuan individu (ability) dan motivasinya (motivation). Kemampuan terbentuk oleh kondisi psikologis dari potensi merujuk pada kemampuan individual (knowledge) dan keahlian maupun ketrampilannya (skill). Motivasi dan kemampuan yang tinggi dimiliki karyawan maka akan memberikan kinerja yang lebih baik pula (Davis dalam Mangkunegara, 2005:67).

\section{Kajian Literatur}

Watkins (1991:253) mendefinisikan pengembangan sumber daya manusia sebagai berikut "The field of study and practice responsible for the fostering of a longterm, workrelated learning capacity at the individual, group, and organizational level of organizations. The organization needs to enhance individuals' capacity to learn, to help groups overcome barriers, and to help in creation a culture which promotes continuous learning". Definisi ini berhubungan dengan teori modal manusia diasumsikan oleh Schultz (1993) bahwa faktor pengetahuan dan keterampilan yang diperoleh selama pendidikan dan pelatihan akan berdampak positif ke orgnisasi. Sementara itu, Garavan et al. (2001) lebih lanjut menjelaskan sumber daya manusia berguna bagi organisasi karena empat hal utama, yaitu:

1. fleksibilitas dan kemampuan beradaptasi

2. peningkatan individu

3. kompetensi

4. pengembangan kompetensi organisasi

5. kerja individu

Seleim et al. (2007) sependapat bahwa modal sumber daya manusia berhubungan positif dengan kinerja organisasi. Sebagai pengembangan sumber daya manusia seperti berdampak secara signifikan peningkatan diri kemampuan pegawai terhadap pelaksanaan tugas dalam mencapai tujuan organisasi.

Kinerja (performance) mengacu pada kadar pencapaian tugas-tugas yang membentuk sebuah pekerjaan karyawan (Simamora dalam Agusty, 2006). Kinerja merefleksikan seberapa baik karyawan memenuhi persyaratan sebuah pekerjaan. Pengertian kinerja adalah pencatatan hasil yang dicapai dalam melaksanakan fungsi-fungsi khusus suatu pekerjaan atau kegiatan bekerja selama periode tertentu yang ditunjukkan melalui proses atau cara bekerja dan hasil yang dicapai.

Sedangkan Byars and Rue dalam Agusty (2006) mendefinisikan kinerja merupakan derajat penyelesaian tugas yang menyertai pekerjaan seseorang. Kinerja adalah yang merefleksikan seberapa baik seseorang individu memenuhi permintaan pekerjaan. Berdasarkan definisi-definisi tersebut, menunjukkan bahwa kinerja merupakan hasil yang bersifat kualitatif dan kuantitatif.

Kinerja organisasi digunakan sebagai indikator keberhasilan atau kapasitas oraginisasi untuk mencapai tujuan secara independen dan efisien (Venkatraman \& Ramanujam, 1986). Pendapat tersebut diterima secara meluas bahwa kinerja organisasi sebagian besar tergantung pada perilaku karyawan yang merupakan sumber keunggulan kompetitif yang berkelanjutan (Huselid et al., 1997). Perilaku dan kemampuan tersebut dibentuk melalui program pelatihan dan pengembangan yang dilaksanakan oleh organisasi. Bukan hanya pada pembentukan perilaku, akan tetapi setiap organisasi bersedia untuk berinvestasi dalam pelaksanaan 
program-program khusus yang bertujuan menciptakan kemampuan dalam pelaksanaan tugastugas secara efektif.

Becker (1964) telah menegaskan investasi untuk peningkatan keterampilan dan pengetahuan melalui program pelatihan lebih penting daripada investasi modal fisik. Studi tentang hubungan penilaian kinerja dan pengembangan sumber daya manusia telah dilakukan bertahun-tahun, antara lain Birdi et al. (2008), Delaney \& Huselid (1996), Delery \& Doty (1996), Huselid et al. (1997), Kayu dan de Menezes (2008). Penelitian lain juga terjadi di beberapa negara seperti Korea, Selandia Baru, Yunani dan Singapura (Bae dan Lawler, 2000; Guthrie, 2001; Vlachos, 2008; Wan et al., 2002).

Dengan munculnya era informasi dalam dekade terakhir, menjadi jelas bahwa laporan keuangan tradisional dianggap tidak cukup untuk memberikan penilaian yang akurat dari nilai perusahaan. Ada faktor yang terkait dengan pengembangan sumber daya manusia yang diasumsikan memiliki efek pada kinerja karyawan, seperti yang diasumsikan oleh GomezMejia et al. (1998) yaitu proses perekrutan, pengelolaan pemberhentian (mutasi), penilaian kemampuan, penghargaan (promosi pekerjaan), kompensasi; pelatihan dan pengembangan (Yang \& Lin, 2009).

Proses perekrutan terkait dengan tindakan dari mencari pegawai yang memenuhi syarat untuk mengisi kekosongan atau memegang posisi yang tersedia. Memilih orang yang tepat dan mampu untuk suatu posisi tertentu bukan hal yang mudah karena secara tidak langsung akan berpengaruh terhadap kinerja organisasi. Penerapan sistem perekrutan yang handal dianggap sebagai titik awal dalam pengembangan sumber daya manusia. Ini mencakup penilaian pada pendidikan dan persyaratan keterampilan sebagaimana yang diharapkan, dan hal itu harus sesuai dengan kebijakan dan prosedur yang dirancang sesuai dengan iklim organisasi.

Terpstra dan Rozell (1993) dalam penelitiannya tentang perekrutan yang ekstensif, pemilihan validasi tes, penggunaan prosedur seleksi secara formal menemukan adanya konektivitas positif antara keuntungan organisasi dan proses seleksi kepegawaian, yang mengarah dan berpengaruh terhadap sejauh mana kinerja organisasi (Becker et al., 2001). Dengan demikian, variabel tersebut akan berdampak pada kinerja karyawan.

Pelatihan dan pengembangan merupakan faktor penting yang mempengaruhi penilaian kinerja. Patrick (2000) mendefenisikan sebagai pengembangan sistematis pengetahuan, keterampilan dan keahlian yang dibutuhkan oleh seseorang untuk melakukan tugas tertentu atau pekerjaan secara efektif. Bartel (2004) menyatakan adanya hubungan antara penerapan program pelatihan dan pertumbuhan produktivitas.

Penerapan program pelatihan juga telah dikaitkan dengan kinerja keuangan (Russell et al., 1985). Untuk melihat efektivitas pelaksanaan program pelatihan dan pengembangan, pemerintah perlu mengkaji perubahan dalam sikap dan keterampilan pegawai, baik sebelum dan setelah program pelatihan dilaksanakan; pemerintah harus mempertimbangkan dan melihat perbedaan prestasi hasil kinerja sebelum dan setelah mengikuti program pelatihan. Pendidikan dan pelatihan (training) dianggap sebagai bagian integral dari administrasi kepegawaian, yang memberikan kontribusi pada administrasi negara, pelaksanaan tugas, peningkatan produktivitas dan peningkatan kemampuan serta dedikasi sebagai Aparat Sipil Negara.

Peluang promosi dalam suatu organisasi dapat terjadi karena kekosongan, baik dari segi pangkat dan jabatan. Lowongan peringkat timbul dalam sistem kerja sebagai sistem poin rating, sedangkan lowongan diposisi (pekerjaan) biasanya didasarkan pada sistem kepegawaian, klasifikasi pekerjaan. Oleh karena itu, promosi menunjukkan gerakan dari posisi satu ke posisi lain dan memiliki status yang lebih tinggi dimana posisi baru menawarkan gaji yang lebih tinggi dari jabatan lama. Hal ini ditegaskan oleh Moenir (1995) yang menyatakan promosi adalah perubahan posisi, dari satu pos ke yang lain dan dievaluasi 
berdasarkan tingkat tanggung jawab, persyaratan kerja atau pendapatan. Selain itu, promosi pekerjaan adalah cara untuk mengembangkan karir karyawan.

Kinerja adalah hasil atau tingkat keberhasilan seseorang secara keseluruhan selama periode tertentu didalam melaksanakan tugas dibandingkan dengan berbagai kemungkinan, seperti standar hasil kerja, target atau sasaran atau kriteria yang telah ditentukan terlebih dahulu dan telah disepakti bersama (Rivai \& Basri,2005).

Menurut Hersey \& Blanchard, kinerja adalah suatu fungsi dari motivasi dan kemampuan. Untuk menyelesaikan tugas atau pekerjaan, seseorang harus memiliki derajat kesediaan dan tingkat kemampuan tertentu. Kesediaan dan tingkat keterampilan seseorang tidaklah cukup efektif untuk mengerjakan sesuatu tanpa pemahaman yang jelas tentang apa yang akan dikerjakan dan bagaimana mengerjakannya (Rivai \& Basri, 2005).

Menurut Prawirosentono (1999) kinerja adalah hasil kerja yang dapat dicapai oleh seseorang atau sekelompok orang dalam suatu organisasi sesuai dengan tanggung jawab masing-masing dalam rangka upaya mencapai tujuan organisasi bersangkutan secara legal, tidak melanggar hukum dan sesuai dengan moral etika. Sedangkan Bernardin (1998) mendefinisikan kinerja sebagai catatan outcome yang dihasilkan dari fungsi suatu pekerjaan tertentu.

Menurut Irawan (1995) kinerja merupakan hasil kerja pegawai atau hasil dari suatu proses atau hasil kerja suatu organisasi. Hasil tersebut dapat ditunjukkan buktinya secara kongkrit dan dapat diukur atau dibandingkan dengan standar yang telah ditentukan. Dengan demikian kinerja dapat digolongkan menjadi tiga yaitu : kinerja organisasi, kinerja proses dan kinerja individu atau pegawai. Ketiga kriteria ini saling berhubungan satu dengan lainnya.

Terpstra dan Rozell (1993) dalam penelitiannya tentang perekrutan yang ekstensif, pemilihan validasi tes, penggunaan prosedur seleksi secara formal menemukan adanya konektivitas positif antara keuntungan organisasi dan proses seleksi kepegawaian, yang mengarah dan berpengaruh terhadap sejauh mana kinerja organisasi (Becker et al., 2001). Dengan demikian, variabel tersebut akan berdampak pada kinerja karyawan.

Pelatihan dan pengembangan merupakan faktor penting yang mempengaruhi penilaian kinerja. Patrick (2000) mendefenisikan sebagai pengembangan sistematis pengetahuan, keterampilan dan keahlian yang dibutuhkan oleh seseorang untuk melakukan tugas tertentu atau pekerjaan secara efektif (lihat model kerangka konseptualnya di Gambar 1).

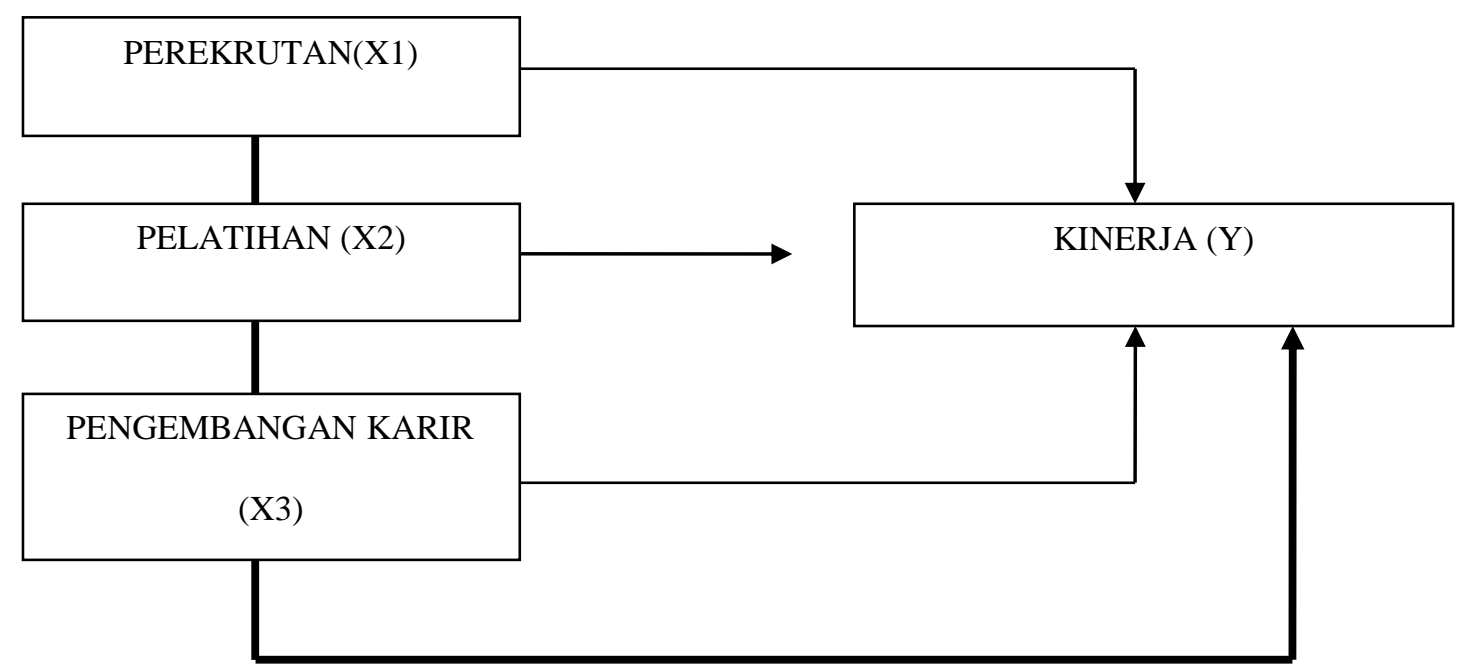

Gambar 1. Model Kerangka Konseptual 
Berdasarkan model konseptual pada Gambar 1, maka hipotesis dalam penelitian ini adalah sebagai berikut:

H1 = Diduga bahwa variabel sumber daya manusia yang terdiri dari perekrutan, pelatihan dan pengembangan karir berpengaruh signifikan baik secara parsial maupun simultan.

$\mathrm{H} 2$ = Diduga Variabel perekrutan berpengaruh secara parsial terhadap kinerja

H3 = Diduga Variabel pelatihan berpengaruh secara parsial terhadap kinerja

H4 = Diduga Variabel pengembangan karir berpengaruh secara parsial terhadap kinerja

\section{Metode Penelitian}

jenis penelitian yang digunakan oleh peneliti adalah penelitian kuantitatif yaitu suatu model penelitian yang mengharuskan akan adanya perhitungan angka-angka, sedangkan pendekatan yang digunakan adalah dengan pendekatan survei yaitu penelitian yang mengambil sampel dari populasi dan menggunakan kuesioner sebagai alat pengumpulan data yang pokok Singarimbun (1989:3).

Untuk memudahkan justifikasi terhadap persepsi pegawai digunakan skala Likert 5 poin. Skala Likert adalah skala yang digunakan dalam quesioner untuk mempermudah responden dalam menjawab pertanyaan, kemudian responden menjawab pertanyaan sesuai dengan kode yang ada dalam quesioner. Objek dalam penelitian ini adalah Bappeda Kabupaten Murung Raya.

Yang menjadi populasi dalam penelitian ini adalah pegawai yang ada lingkungan pemerintahan Kabupaten Murung Raya yang terdiri dari beberapa kantor SKPD di lingkungan pemerintahan Kabupaten Murung Raya.

Sampel dalam penelitian ini ditentukan sebanyak 100 orang pegawai, teknik yang digunakan Accidental Random Sampling, pengambilan sampel secara acak terhadap responden yang paling mudah ditemui dan bersedia berpartisipasi dalam pengisian kuisioner.

Teknik analisis data yang digunakan dalam penelitian ini menggunakan regresi linear berganda dengan bantuan program SPSS versi 17.0 dengan persamaan regresi :

$\mathrm{Y}=\mathrm{a}+\mathrm{b} 1 \mathrm{X} 1+\mathrm{b} 2 \mathrm{X} 2+\mathrm{b} 3 \mathrm{X} 3+\mathrm{e}$

\section{Keterangan :}

$Y=$ Kinerja

$\mathrm{a}=$ Konstanta

$\mathrm{b} 1=$ Koefisien regresi dari variabel $\mathrm{X} 1$

b2 = Koefisien regresi dari variabel X2

b2 = Koefisien regresi dari variabel X2

$\mathrm{X} 1=$ Variabel Perekrutan

$\mathrm{X} 2=$ Variabel Pelatihan

X3 = Variabel Pengembangan Karir

$\mathrm{e}=$ Variabel lain yang tidak termasuk dalam model

Sebelum dilakukan pengujian dengan analisis regresi, data penelitian diuji dengan uji asumsi klasik yang terdiri dari : uji normalitas, uji heterokedastisitas, dan uji multikolonieritas. Kemudian untuk pengujian hipotesis secara simultan menggunakan Uji F, dan untuk pengujian hipotesis secara parsial menggunakan Uji t. Sedangkan untuk menentukan variabel yang paling dominan mempengaruhi produktivitas menggunakan nilai standrdized coefficient beta. 


\section{Hasil Penelitian dan Pembahasan}

Proses analisis data untuk menemukan suatu kesimpulan pada penelitian ini dijabarkan melalui langkah-langkah berikut:

1. Uji Validitas

Uji validitas yang digunakan dalam penelitian ini yaitu dengan mengikuti kaedah product moment pearson (Sutrisno Hadi, 1994) yaitu:

a. Korelasi antar butir dengan faktor harus fositif

b. Peluang ralat $\mathrm{p}$ dari korelasi tersebut minimal $5 \%$

Uji validitas dengan metode ini, merupakan uji validitas item, dasar kerjanya dengan komputasi korelasi antar setiap item dengan skor total tes sebagai kriteria validitasnya. Adapun hasil yang diperoleh dari uji validitas kuisioner yang dilakukan terhadap 100 responden seperti pada tabel 4.1 dibawah ini.

Tabel 1. Hasil Ringkasan Hasil Tes Validitas Kuisioner

\begin{tabular}{ccccc}
\hline Variabel & Butir pertanyaan & $\mathrm{r}$ & $\mathrm{p}$ & Status \\
\cline { 2 - 5 } X1 & $\mathrm{X} 1.1$ & 0,771 & 0,000 & Valid \\
\hline Perekrutan & $\mathrm{X} 1.2$ & 0,791 & 0,000 & Valid \\
\hline X2 & $\mathrm{X} 2.1$ & 0,811 & 0,000 & Valid \\
\hline Pelatihan & $\mathrm{X} 2.2$ & 0,755 & 0,000 & Valid \\
\hline X3 & $\mathrm{X} 3.1$ & 0,730 & 0,000 & Valid \\
\cline { 2 - 5 } Pengembangan Karir & $\mathrm{X} 3.2$ & 0,882 & 0,000 & Valid \\
\hline
\end{tabular}

2. Uji Reliabilitas

Tekhnik uji releabilitas yang digunakan dalam penelitian ini adalah tekhnik analisis dengan menggunakan Alpha Cronbach untuk menunjukan releabilitas, konsistensi internal dan homogenitas antar butir (item) dalam variabel yang diteliti. Langkah ujinya adalah dengan komputasi korelasi antar item, dengan nilai rata-rata korelasinya. Ghozali (2013: 48) mengemukakan bahwa suatu variabel dikatakan reliabel jika memberikan nilai cronbach alpha $>0,60$. Adapun hasil dari uji reliabilitas dapat dilihat pada tabel 2 ringkasan test reliabilitas kuisioner berikut:

Tabel 2. Hasil Ringkasan Test Reabilitas Kuisioner

\begin{tabular}{lccc}
\hline \multicolumn{1}{c}{ Variabel } & Nilai Alpha Cronbach & Nilai Kritis & Status \\
\hline X1 Perekrutan & 0.786 & 0,60 & Reliabel \\
\hline X2 Pelatihan & 0.791 & 0,60 & Reliabel \\
\hline X3 Pengembangan Karir & 0.821 & 0,60 & Reliabel \\
\hline
\end{tabular}

Hasil pada tabel 2 diatas menunjukan bahwa alpha yang distandardisasi untuk semua variabel $\mathrm{X}$ dan $\mathrm{Y}$ mempunyai nilai yang lebih besar dari 0,6 dengan demikian maka itemitem pertanyaan seluruhnya bisa dianggap reliabel dalam melakukan fungsinya.

3. Uji Multikolinearitas

Tabel 3 . Hasil Uji Multikolinieritas

\begin{tabular}{cccl}
\hline Variabel & Tolerance & VIF & Kesimpulan \\
\hline Perekrutan (X1) & .732 & 1.366 & Tidak terjadi multikolinieritas \\
\hline Pelatihan (X2) & .569 & 1.759 & Tidak terjadi multikolinieritas \\
\hline Pengembangan Karir (X3) & .680 & 1.471 & Tidak terjadi multikolinieritas
\end{tabular}


4. Uji Autokorelasi

Untuk dapat mendiagnosis adanya autokorelasi dalam suatu model regresi dilakukan melalui pengujian terhadap nilai uji Durbin-Watson (Uji DW) dengan ketentuan sebagai berikut:

DW Kurang dari 1,10, dapat disimpulkan Ada Autokorelasi

DW diantara 1,10 dan 1,54 dapat disimpulkan Tanpa Kesimpulan

DW diantara 1,55 dan2,46 dapat disimpulkan Tidak Ada Autokrelasi

DW diantara 2,46 dan 2,90 dapat disimpulkan Tanpa Kesimpulan

DW Lebih dari 2,91 dapat disimpulkan Ada autokorelasi

Berdasarkan pengujian yang dilakukan, maka hasil pengujian autokorelasi dapat ditampilkan dalam tabel 4.

Tabel 4. Hasil Uji Autokorelasi

\begin{tabular}{cc}
\hline Nilai DW-hitung & Keputusan \\
\hline 2.190 & Tidak Ada Autokorelasi \\
\hline
\end{tabular}

Berdasarkan hasil dari tabel 4 menunjukan bahwa hasil analisis yang dilakukan koefisien Durbin-Watson sebesar 2.190, maka keputusannya bahwa dalam model Regresi tidak ada Autokorelasi.

5. Analisis Regresi Linear Berganda

Tabel 5. Hasil Koefisien Regresi Linier Berganda

\begin{tabular}{ccc}
\hline Variabel & b & Koefisien \\
\hline Perekrutan X1) & b1 & .021 \\
\hline Pelatihan (X2) & b2 & .255 \\
\hline Pengembangan Karir (X3) & b3 & .466 \\
\hline
\end{tabular}

Berdasarkan pada data temuan pada tabel 5, maka persamaan Regresi yang terbentuk adalah sebagai berikut:

$\mathrm{Y}=0.079+0,021 \times 1+0,255 \times 2+0,466 \times 3+e$

Teknik uji $\mathrm{F}$ yang dipergunakan yaitu dengan membandingkan antara $\mathrm{F}$ hitung dengan $\mathrm{F}$ tabel, jika $\mathrm{F}$ hitung lebih besar dari $\mathrm{F}$ tabel maka keputusannya adalah $\mathrm{H}_{\mathrm{o}}$ dan $\mathrm{H}_{\mathrm{a}}$ diterima. Dengan tingkat keyakinan 95\% dan derajat kebebasan $(\mathrm{k}-1)(\mathrm{n}-\mathrm{k})$ maka tabel untuk $\mathrm{F}$ $(0,05)(4)(97)=2,3092$. Perbandingan antara $F$ hitung dengan $F$ tabel dapat dilihat dalam tabel 6.

\section{Tabel 6. Hasil Perbandingan F Hitung dan F Tabel}

\begin{tabular}{ccc}
\hline F Hitung & F Tabel & Sig. \\
\hline 21.394 & 2,3092 & 0,000 \\
\hline
\end{tabular}

Dari tabel 6 diatas ternyata F hitung lebih besar (21.394) dari F tabel $(2,3092)$, sehingga keputusannya adalah menolak $\mathrm{H}_{0}$ dan menerima $\mathrm{H}_{\mathrm{a}}$ yang artinya variabel $\mathrm{X} 1, \mathrm{X} 2, \mathrm{X} 3$ secara bersama-sama berpengaruh pada pada tingkat kinerja pegawai di lingkungan Pemerintahan Kabupaten Murung Raya. 
Teknik uji $\mathrm{T}$ yang dilakukan yaitu dengan melihat nilai t signifikan pada hasil pengolahan data melalui SPSS. Dalam penelitian ini $\alpha$ yang digunakan yaitu sebesar $5 \%(0,05)$. Keputusannya, jika nilai t signifikan $<$ terhadap $\alpha$ maka $\mathrm{H}_{0}$ akan ditolak dan menerima $\mathrm{H}_{\mathrm{a}}$. Hasil perhitungan $\mathrm{t}$ signifikan masing-masing variabel bebas (kinerja karyawan) ditampilkan pada Tabel 7.

Tabel 7. Hasil Rangkuman Nilai t Signifikan

\begin{tabular}{ccc}
\hline Variabel & $\begin{array}{c}\text { Signifikan } \\
\mathbf{T}\end{array}$ & $\begin{array}{c}\mathbf{H}_{\mathbf{a}} \\
\text { diterima/ditiolak }\end{array}$ \\
\hline Perekrutan (X1) & .823 & Ditolak \\
\hline Pelatihan (X2) & .037 & Diterima \\
\hline Pengembangan Karir (X3) & .000 & Diterima \\
\hline
\end{tabular}

Dari hasil rangkuman nilai T signifikan pada tabel 8 diatas terlihat bahwa, nilai signifikan T untuk X1 $=0,823$, artinya X1 (Perekrutan) signifikan dalam mempengaruhi kinerja. Jadi variabel X1 (Perekrutan) signifikan dalam mempengaruhi $\mathrm{Y}$ (Kinerja) atau $\mathrm{H}_{0}$ ditolak dan $\mathrm{H}_{\mathrm{a}}$ diterima.

Sedangkan untuk Variabel X2 (Pelatihan) dan X3 (Pengembangan Karir) nilai signifikan t lebih kecil dari 5\% yaitu 0.037 (X2) dan 0.000 (X3). Jadi variabel X2 dan X3 signifikan dalam mempengaruhi Y (Kinerja) atau dapat dikatakan bahwa $\mathrm{H}_{0}$ ditolak dan $\mathrm{H}_{\mathrm{a}}$ diterima.

Dari hasil analisis yang dilakukan, diperoleh bahwa variabel pengembangan sumber daya manusia yang terdiri dari perekrutan, pelatihan dan pengembangan karir berpengaruh siginifikan secara simultan terhadap Kinerja. Artinya jika tingkat pengaruh pengembangan sumber daya manusia yang terdiri dari perekrutan, pelatihan dan pengembangan karir yang dilakukan oleh pemerintah Kabupaten Murung Raya, maka mengakibatkan makin tinggi juga tingkat Kinerja pegawainya. Persamaan regresi yang didapat dari hasil analisis tersebut adalah:

$\mathrm{Y}=0.079+0,021 \times 1+0,255 \times 2+0,466 \times 3+e$

Untuk melihat dominasi pengaruh dari variabel bebas terhadap variabel terikatnya, maka bisa dilihat koefisien beta (koefisien regresi baku). Nilai koefisien regresi baku antar variabel bebas dapat dibandingkan, karena nilainya telah distandarisasi sehingga variabel bebas (pengembangan sumber daya manusia yang terdiri dari perekrutan, pelatihan dan pengembangan karir) yang memiliki koefisien regresi baku yang lebih besar, berarti akan memberi pengaruh yang lebih besar pula pada variabel terikatnya.

Hasil pengolahan data penelitian ini, ternyata variabel bebas yang memiliki beta terbesar adalah variabel pengembangan karir (X3) yaitu sebesar 0,466. Oleh karena itu dapat dikatakan bahwa variabel pengembangan karir (X3) yang memiliki pengaruh terbesar terhadap Kinerja.

Hasil pembuktian hipotesa pertama $(\mathrm{H} 1)$ yaitu keputusannya menolak $\mathrm{H}_{0}$ dan menerima $\mathrm{H}_{\mathrm{a}}$ yang artinya uji $\mathrm{F}$ terhadap persamaan regresi yang diperoleh dari penelitian ini menunjukan hasil bahwa, secara bersama-sama ke tiga variabel pengembangan sumber daya manusia berpengaruh terhadap tingkat Kinerja Pegawai di lingkungan pemerintahan Kabupaten Murung Raya.

Implikasi hasil uji $\mathrm{F}$ bagi pemerintah Kabupaten Murung Raya adalah jika pegawai ingin meningkatkan tingkat kinerjanya maka perlu menekankan pada tiga faktor tersebut yaitu berturut-turut perekrutan pegawai, pelatihan pegawai dan pengembangan karir pegawai. Hal 
ini harus dilakukan secara terus menerus (continues improvement) dalam usaha untuk meningkatkan hasil kinerja pegawainya.

Untuk mendukung keterangan diatas dapat juga kita lihat hasil $\mathrm{R}^{2}$ (Koefisien Determinasi) Regresi yaitu sebesar 0,401 atau 40,1\%. Hal ini dapat diartikan bahwa sebanyak 40,1\% Tingkat Kinerja Pegawai pemerintah Kabupaten Murung Raya dijelaskan oleh variabel pengembangan sumber daya manusia yang terdiri dari perekrutan, pelatihan dan pengembangan karir. Sedangkan sisanya sebesar 59,9\% dijelaskan oleh variabel lain diluar variabel pengembangan sumber daya manusia yang terdiri dari perekrutan, pelatihan dan pengembangan karir Pegawai pemerintah Kabupaten Murung Raya.

\section{Kesimpulan}

Berdasarkan hasil analisis dapat disimpulkan bahwa Variabel Pelatihan (X2) dan Pengembangan Karir (X3) berpengaruh secara signifikan dan positif terhadap Kinerja. Sedangkan untuk Variabel Perekrutan (X1) tidak berpengaruh signifikan terhadap kinerja.

Adapun saran yang perlu direkomendasikan dalam penelitian ini adalah perlu memfokuskan hasil penelitian yang memilki pengaruh signifikan yaitu Unsur pengembangan sumber daya manusia yang terdiri dari perekrutan, pelatihan dan pengembangan karir yang perlu segera diperbaiki adalah variabel pengembangn karir, karena unsur inilah yang paling besar pengaruhnya terhadap kinerja pegawai di lungkungan pemerintah Kabupaten murung Raya. Untuk dapat meningkatkan Pengembangan karir Pegawainya, maka pemerintah Kabupaten Murung Raya dapat melakukan usaha-usaha seperti mengadakan pelatihan secara berkala, melakukan perekrutan pegawai yang sesuai dengan bidangnya serta melakukan pengembangan karir bagi setiap pegawainya. Hal ini harus dilakukan secara berkala dan terus menerus mengingat pentingnya ketiga unsure ini untuk dapat meningkatkan kinerja setiap pegawainya.

\section{DAFTAR PUSTAKA}

Allen, NJ., Meyer PJ. And Smith CA., 1993, "Commitment to Organizations and Occupations: Extention and Test of a Three - Component Conceptualization", Journal of Applied Psychology, Vol. 78, No. 4

Amstrong, Michael, 1994, "Handbook of Personal Management Practise", 4th Edition, Kopan Page Ltd., London

Anwar Prabu Mangkunegara, DR., Msi., 2006, Evaluasi Kinerja SDM, Edisi Kedua, Refika Aditama, Bandung.

Becker, BE, Huselid, ME \& Ulrich, D. 2001. HR Scorecard: Menghubungkan orang, strategi, dan kinerja. Boston: Harvard Business School Press.

Bernadin, H. J. 2007. Manajemen Sumber Daya Manusia: Sebuah Pendekatan Eksponensial. Ed-4. NewYork: McGraw-Hill Irwin, 253-277.

Delaney, J. T. \& Huselid, M. A. 1996. "Dampak dari Praktek Manajemen Sumber Daya Manusia pada Persepsi dari Kinerja Organisasi ${ }^{i e}$. Akademi Manajemen Journal, 39, 94969.

Dessler, G. 2003 Manajemen Sumber Daya Manusia. Jilid 2. Edisi Kesembilan. Jakarta: PT Indeks Kelompok Gramedia.

Gomez-Mejia, LR, Balkin, DB \& Cardy, RL 1998. Mengelola Sumber Daya Manusia. Prentice-Hall, Englewood Cliffs, NJ.

Hasibuan, M. S. P. 2006. Manajemen Sumberdaya Manusia. Edisi Revisi. Jakarta: Bumi Akasara.

Nitisemito, S. 1997. Pengembangan Sumber Daya Manusia. Jakarta: Balai Pustaka.

Patrick, J. 2000. "Pelatihan". Dalam N. Chmiel (Ed.) Pengantar Kerja dan Psikologi Organisasi (100-125). Oxford, Inggris: Blackwell. 
Siagian, S. P. 2001. Manajemen Sumber Daya Manusia. Jakarta: Bumi Aksara.

Siagian, S. P. 2006. Manajemen Sumber Daya Manusia. Jakarta: PT. Bumi Aksara.

Thoha, M. 2007. Perilaku Organisasi, Konsep Dasar dan Aplikasinya. Jakarta: PT. Raja Grafindo Persada.

Undang Undang Nomor 5 Tahun 2014 Tentang Aparatur Sipil Negara.

Vlachos, I. 2008. "Pengaruh Praktek Sumber Daya Manusia pada Kinerja Organisasi: Bukti dari Yunaniee. International Journal of Manajemen Sumber Daya Manusia, 19 (1), 74 97.

Wan, D., Kok, V. \& Ong, C. H. 2002. Strategis Manajemen Sumber Daya Manusia dan Kinerja Organisasi di Singapura. Kompensasi dan Manfaat Review, 34, 33-42.

Winardi, L. 2000. Kepemimpinan Hearts Manajemen. Jakarta: PT. Rhineka Cipta.

Wright, P., Gardner, T., Moynihan, L. \& Allen, M. 2005. Hubungan antara Praktek SDM dan Kinerja Perusahaan: Memeriksa Urutan Kausal. Personil Psikologi, 58. 